\title{
RESEARCH REPORT \\ GROWTH REACTIONS OF SUB-ALPINE NORWAY SPRUCE (PICEA ABIES (L.) KARST.) FOLLOWING ONE-SIDED LIGHT EXPOSURE (CASE STUDY AT DAVOS “LUSIWALD”)
}

\author{
OTTO U. BRÄKER and ERNST BAUMANN \\ Swiss Federal Research Institute WSL \\ CH-8903 Birmensdorf \\ Switzerland
}

\begin{abstract}
In 1982, several rectangular openings were cut in a 100 year old sub-alpine Norway spruce forest stand to initiate regeneration at the Lusiwald site at Davos, Switzerland. The openings on the steep, northfacing slope created rapid changes to the environment of the border trees. Growth reactions of these border trees were compared and analysed with reference trees from the adjacent closed canopy stand in 1997. The radial growth pattern of the two data sets differed within the 14-year period since the openings were cut; the border trees showed growth releases. The growth reaction at the stem base was larger than at breast height. Changes in wind exposure may have influenced border trees to adapt their root systems. Sub-alpine Norway spruce stands aged around 100 years, which are usually considered slow-growing on a north aspect, still seem capable of reacting to greater resource availability such as sudden light changes.
\end{abstract}

Keywords: Radial increment, tree rings, forest openings, forest gaps, growth release, Picea abies, Switzerland, Davos.

\section{Zuwachsreaktionen von Gebirgsfichten nach einseitiger Freistellung}

Im Lusiwald, einem subalpinen, nordexponierten Fichtenwald mit starkem Baumholz, wurden zur Einleitung der Verjüngung 1982 versuchsweise rechteckige Schlitze geschlagen. Diese schräg zur Hangrichtung angelegten, nordwest-südost orientierten Bestandesöffnungen ergaben in den ersten Jahren neue Waldränder mit drastischen Änderungen der Lebensumstände für die dort stehenden Fichten. Acht Gebirgsfichten im Alter von etwa 100 Jahren, am Bestandesrand auf der sonnenexponierten Südseite der Schlitze, und neun Bäume im Bestandesinnern wurden hangaufwärts auf Brusthöhe sowie hangabwärts auf Stockhöhe angebohrt. Die radialen Zuwachsmuster der beiden Straten "Randbaum" und "Kontrolle" zeigen klare Unterschiede in der 14-jährigen Periode seit der Bestandesöffnung: Randbäume zeigen Zuwachssteigerung an. Die Zuwachsreaktionen am Stammfuss sind ausgeprägter als auf Brusthöhe. Änderungen der Standortsverhältnisse, auch in Bezug zur Windbelastung, könnten die Randbäume zur Anpassungen ihres Wurzelsystems und damit zu breiteren Jahrringen am Stock veranlasst haben. Subalpine Fichtenbestände um Alter 100 Jahre, welche normalerweise in Nordexposition als langsam wachsend und wenig reaktionsfähig eingestuft werden, sind auf plötzliche Freistellung und Änderungen des Lichtgenusses trotzdem noch zu messbaren Reaktionen fähig.

Impact des facteurs environnementaux sur la croissance des épicéas situés à la lisière du peuplement (Picea abies (L.) Karst.) à l'étage subalpin

Dans le Lusiwald, à Davos, des ouvertures en fentes rectangulaires ont été crées en 1982 dans une pessière subalpine exposée au nord afin d'engager la régénération. Ces ouvertures, aménagées en travers de la pente et orientées du nord-ouest au sud-est, ont rapidement modifié les conditions écologiques des épicéas situés à la lisière du peuplement. Deux carottes ont été prélevées sur des arbres, l'une à hauteur d'homme du côté amont, et l'autre au bas du tronc du côté aval. Il s'agissait de huit épicéas d'une centaine d'années situés en lisière de la fente exposée au sud et de neuf arbres à l'intérieur du peuplement. Le patron de croissance des arbres de lisière et des arbres témoins se caractérise par des différences notables au cours des 14 ans qui sont suivi l'ouverture du peuplement: les arbres de lisière inscrivent une reprise de croissance. L'impact des facteurs environnementaux sur la croissance est plus marqué au pied de l'arbre qu'à hauteur d'homme. Ces changements des conditions du milieu pourraient avoir amené les arbres de lisière à adapter aussi leur système racinaire et à former ainsi des cernes plus larges au bas du tronc. A 
l'étage subalpin, les peuplements d'épicéas d'une centaine d'année, considérés généralement comme des essences à croissance lente et à faible capacité d'adaptation sur les versants nord, sont tout même capables de réagir visiblement aux changements apportés par une mise en lumière soudaine. (French translation: Monique Dousse, WSL)

Keywords: disturbance, regeneration, light limitation, tree rings.

\section{INTRODUCTION}

In 1982, several rectangular openings were cut to initiate regeneration in a $c a$. 100-year old sub-alpine Norway spruce (Picea abies (L.) Karst.) forest stand at the Lusiwald site at Davos, Switzerland (Figure 1). The openings, which are oriented northwest-southeast on the steep, northfacing slope, created rapid changes to the environment of the border trees. Light is a known limiting factor at this site and aspect (Röhrig 1982). The growing season is short at this elevation and, at the sub-alpine level, older trees are expected to react slowly to environmental changes (Mayer and Ott 1991).

Growth reactions of border trees from the openings were analysed and compared with reference trees from the closed canopy stand in 1997. Little is known about growth reactions under such conditions. Numerous studies related to various forest treatments (thinning, clear cuttings, selection forest) have examined growth and yield reactions usually on a stand-wide level. Gap studies usually analyse regeneration and do not consider growth reactions of the remaining trees (Bosch et al. 1992, Cherubini et al. 1996). Urban (1993) sampled white spruce (Picea glauca (Moench) Voss) from the edge of a road and compared them to samples taken from trees from the interior of mixed stands. Root diameter growth of the spruce increased along the road clearing. White spruce trees appear to stabilise themselves by changing their growth pattern and the distribution of wood strength after wind stress increases.

The objectives of this study are to answer the following questions:

- Do border trees show any reaction or changes in growth trend after the 1982 opening?

- Do growth changes and reactions vary between stem heights?

\section{MATERIAL AND METHODS}

Trees recording growth reactions were chosen at the northeastern edge of one of several openings, where the most prominent responses, if any, would be expected. Eight border trees on the sunexposed side of the opening and nine reference trees within the closed stand nearby were cored at DBH (south side/upper slope; see Table 1) and at ground level (north side/lower slope). Sample size was kept small in deference to the private forest ownership, to minimize possible damage to trees that protect against rock fall and avalanches, and because this is a pilot study.

Two subsets were desiganted "border trees" and "reference trees". In each subset the ring values of each sampling height group were averaged. Regional Curve Standardisation (RCS), used to preserve as much low-frequency variability as pos-

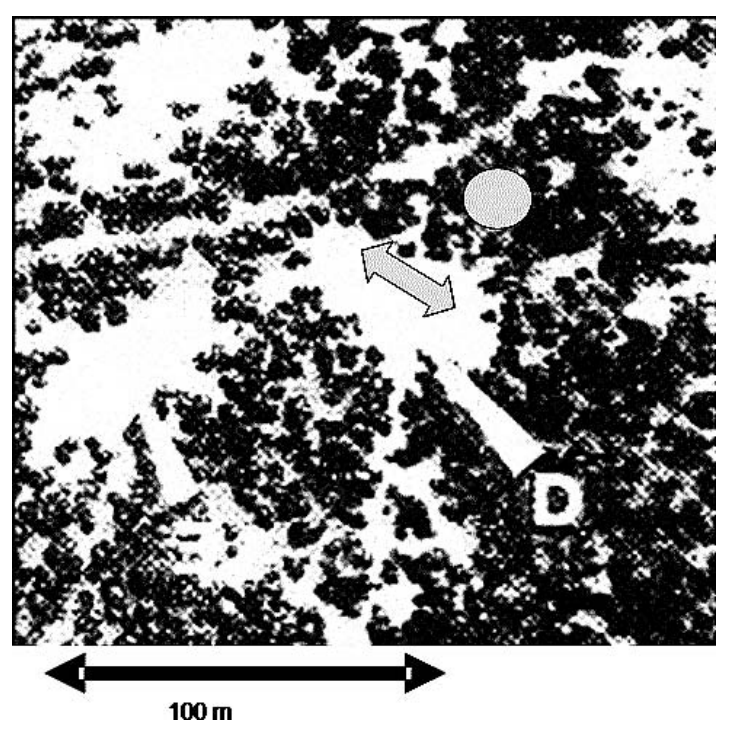

Figure 1. Aerial photograph of the openings cut in 1982 in the forest; north is at the top of the photograph. The location of the analysed opening is marked with letter " $D$ ", border trees along double-arrow, reference trees within the stand are located at the circle. Photo taken by Auer and Clement, November 1988. 
Table 1. Coring list, opening D, sampling June, 24th and 25th 1997. Sampling height 1.3 m, coring direction south.

\begin{tabular}{|c|c|c|c|c|c|c|c|}
\hline $\begin{array}{c}\text { Tree } \\
\text { Number }\end{array}$ & $\begin{array}{c}\text { Bark } \\
\text { Thickness }^{1} \\
(\mathrm{~mm})\end{array}$ & $\begin{array}{l}\text { Crown- } \\
\text { Propor- } \\
\text { tion }^{2}(\%)\end{array}$ & Crown-shape & Social Status & $\begin{array}{c}\text { June Potential } \\
\text { Sunshine-period*3 }\end{array}$ & $\begin{array}{c}\text { June Daily } \\
\text { Potential } \\
\text { Sunshine } \\
\text { Duration } \\
\text { (Hours) }\end{array}$ & $\begin{array}{c}\text { Growing } \\
\text { Season } \\
\text { Average } \\
\text { Sunshine } \\
\text { Duration }^{3} \\
\text { (Hours) }\end{array}$ \\
\hline \multicolumn{8}{|c|}{ Border Trees } \\
\hline 60 & & $>50$ & One-sided & Dominant & $\begin{array}{l}0900-1330 \\
1600-1800\end{array}$ & 6.5 & 3.9 \\
\hline 61 & 4 & & & Suppressed & $\begin{array}{l}0930-1430 \\
1600-1800\end{array}$ & 7 & 4.4 \\
\hline 63 & 7 & 60 & Round & Dominant & $1000-1430$ & 4.5 & 2.9 \\
\hline 131 & 4 & 60 & One-sided & Dominant & $1000-1700$ & 7 & 3.6 \\
\hline 148 & 7 & 50 & One-sided & Dominant & $\begin{array}{l}0945-1630 \\
1730-1830\end{array}$ & 8.25 & 4.6 \\
\hline 167 & 5 & 60 & One-sided & Dominant & $1000-1700$ & 7 & 4.4 \\
\hline 426 & 4 & 50 & Round & Dominant & $1100-1900$ & 8 & 5.4 \\
\hline 434 & 8 & 60 & Round & Co-dominant & $1130-1700$ & 5.5 & 4.1 \\
\hline \multicolumn{8}{|c|}{ Reference Trees Within the Closed Canopy Stand } \\
\hline 109 & 8 & 30 & Round & Dominant & $1200-1300$ & 1 & 0.4 \\
\hline 110 & 4 & 60 & One-sided & Dominant & $1130-1200$ & 0.5 & 0.2 \\
\hline 112 & 8 & 55 & One-sided & Dominant & - & & 0.1 \\
\hline 114 & 6 & 50 & Round & Co-dominant & $1330-1400$ & 0.5 & 0.5 \\
\hline 117 & 7 & 50 & Round & Dominant & - & & 0.6 \\
\hline 121 & 6 & 55 & One-sided & Dominant & $1100-1200$ & 1 & 0.6 \\
\hline 456 & 5 & 55 & One-sided & Co-dominant & - & & 0.3 \\
\hline 458 & 8 & 55 & One-sided & Dominant & $1130-1215$ & 0.75 & 1.0 \\
\hline 467 & 4 & 55 & Round & Dominant & - & & 0.0 \\
\hline
\end{tabular}

* Sunshine readings at DBH with "Sonnenkompass" (Schütz and Brang 1995).

${ }^{1}$ Differences in mean and variance not significant $(\mathrm{p}<0.05)$.

${ }^{2}$ Differences in mean and variance significant $(\mathrm{p}<0.05)$.

${ }^{3}$ Differences in mean and variance significant $(\mathrm{p}<0.05)$.

sible in tree-ring chronologies (Mitchell 1967; Becker et al. 1995, 1990; Esper et al. 2003), is an advanced method of tree-ring de-trending. A test with RCS-type indexing was conducted to avoid differences within and between the subsets and to eliminate aging effects (improving signal/noise ratio). To keep the mid- to high-frequency signal during indexing, the Hugershoff function approach (Pollanschütz 1966; Bräker 1981) with a stiff ageing trend was applied to all the individuals in a subset.

Hugershoff function:

$$
\text { ring width }=\mathrm{a} \times \mathrm{t}^{\mathrm{b}} \times \mathrm{e}^{\mathrm{c} \cdot \mathrm{t}}
$$

where $\mathrm{t}=$ cambial year and $\mathrm{a}, \mathrm{b}, \mathrm{c}=$ coefficients. This deterministic function in time, adjusted in a calibration period before the openings, also permits extrapolation in time for a verification period.

Response functions (Fritts 1976; program PRECON version 5.17, 1999 by Hal Fritts) were calculated for a climate-growth model based on monthly temperatures and precipitation at the climate station Davos and on the growth rings of the reference trees at $\mathrm{DBH}$. The proportion of radial growth between ground level and DBH is calculated by a periodic sum of corresponding rings at both heights and referenced as taper. Sunshine readings at DBH were made with an instrument called a "Sonnenkompass" or horizontoscope (Schütz and Brang 1995), which shows times of an open horizon at the measuring position for any month during the vegetation season. 


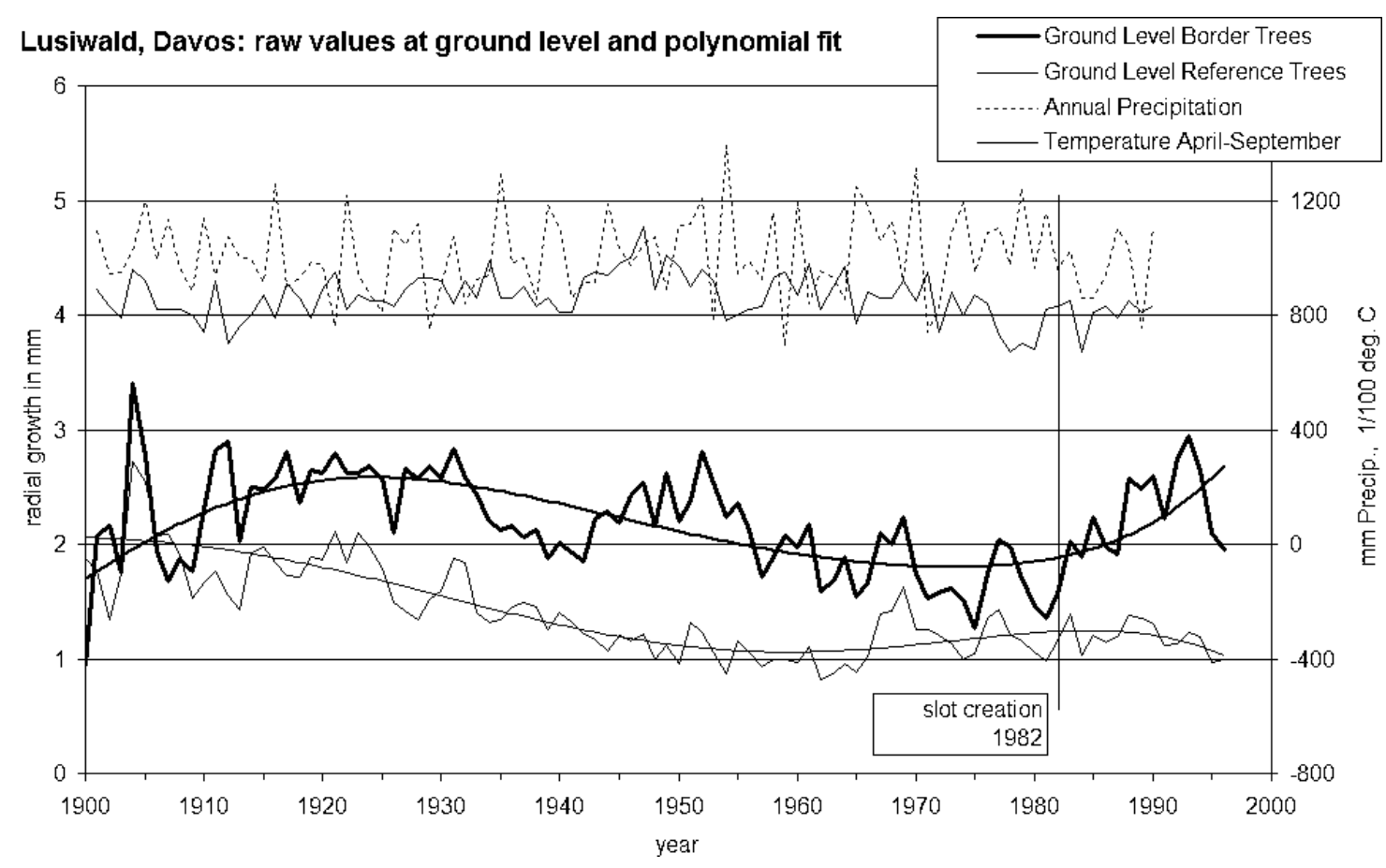

Figure 2. Radial growth curves and polynomial fits at ground level, group averages for border trees and reference trees from the closed canopy stand at the Lusiwald site, Davos; added on top are time series of temperature and precipitation at the Davos meteorological station. Growth differences during the whole lifetime of the two subsets are caused by variances of the social position of individuals. Reference trees show a more horizontal growth trend since 1950 while the growth of border trees clearly increased after the 1982 opening.

\section{RESULTS AND DISCUSSION}

The radial growth pattern of the two data sets show differences within this 14-year period since the creation of the openings: the border trees showed growth releases (Figures 2 and 3). Table 1 shows the maximum potential sunshine period and duration in hours for June and the average daily potential sunshine duration during the growing season. The sunshine period variability as well as the difference of approx. 4-5 hours daily sunshine between the two data sets documents the extreme light increase $(\mathrm{p}<0.05)$ for the border trees (Mayer and Ott 1991). The growth reaction at the stem base was stronger than at breast height. The average radial growth at stem base increased by $40 \%$ and at DBH by $17 \%$ after the creation of the gaps in 1982 in relation to the previous 14 years (the corresponding increase of tree-ring indices was 53\% and 21\%). The changes in competition at canopy and root levels as well as the increased wind exposure may have influenced border trees to adapt their root systems.

The proportion of radial growth between ground level and DBH (taper) is shown in Table 2. Radial growth at ground level is expected to be larger than at $\mathrm{DBH}$, resulting in a taper value above $100 \%$. The individual tree variation in growth taper between the two time spans is large, especially for reference trees. For the border trees in the 14-year period before the opening (19681981) the mean taper is similar to the taper for reference trees $(120 \%)$. Mean taper clearly increases ca. $46 \%$ (164 vs. 112\%) for border trees after the opening (1983-1996). One aspect of this result is the clear reaction of radial growth in the lowest bole level, which might not be detected by the conventional taper ratio (tree height/DBH) applied in forest mensuration studies. In addition, we found no significant change in bark thickness (Table $1 ; \mathrm{p}<0.05)$ between border and reference 


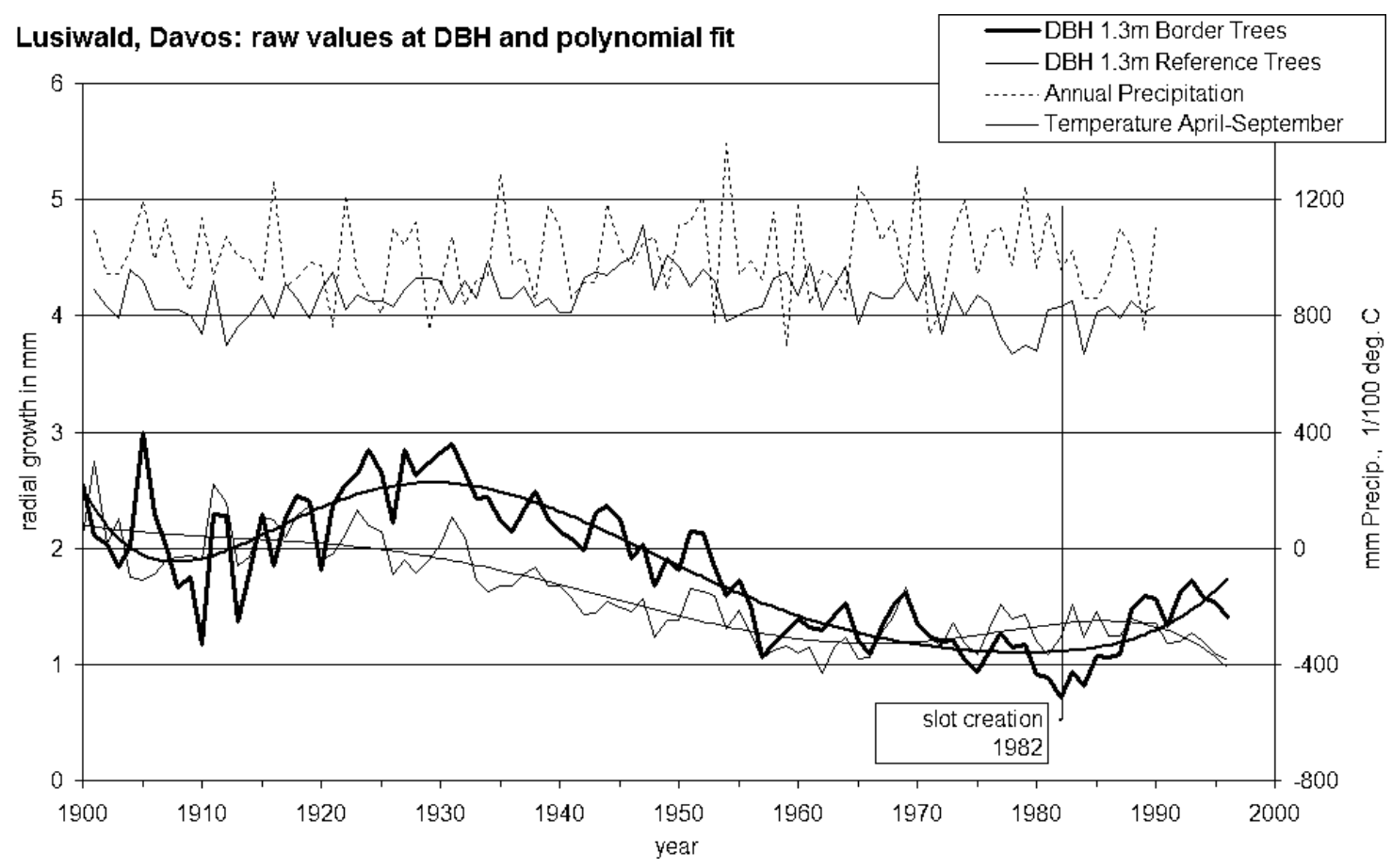

Figure 3. Radial growth curves and polynomial fits at DBH-level, group averages for border trees and reference trees from the closed canopy stand for the Lusiwald site, Davos; added on top are time series of temperature and precipitation at the Davos meteorological station. Growth differences during the whole lifetime of the two subsets are caused by variances of the social position of individuals. Reference trees express a fairly horizontal growth trend since 1950 while the growth of border trees, despite low growth since the 1970s, clearly increased after the 1982 opening.

trees. Another aspect of the growth release by light is documented by the significant differences (Table $1, \mathrm{p}<0.05$ ) of crown proportion. Although the coring direction of the two sampling levels was opposite, the difference in age among heights could be estimated for some of the trees and gave a mean difference of 11 years.

We recognise that the sample size for this study is small, particularly because individual growth responses varied greatly. Some growth level differences between border and reference trees before 1982 are caused by the different social status of each individual tree. This can be observed in Figure 2 and Figure 3. Our selection of border trees may have been biased towards more vital trees. Unknown mortality of former border trees may have altered the original border. The increment at DBH of border trees was $10 \%$ less than that of the reference trees in the 14-year period before 1982. The sample size in this preliminary study is too small to homogenise the material and add stratification for social status.

The Hugershoff functions chosen for indexing resulted in parameters as follows:

Ground level-reference trees:

$\mathrm{a}=308.319, \quad \mathrm{~b}=-0.11336, \quad \mathrm{c}=-0.0052$

Ground level-border trees:

$\mathrm{a}=111.987, \quad \mathrm{~b}=0.37060, \quad \mathrm{c}=-0.0162$

DBH level-reference trees:

$\mathrm{a}=248.545, \quad \mathrm{~b}=-0.0468, \quad \mathrm{c}=-0.0061$

DBH level-border trees:

$\mathrm{a}=244.829, \quad \mathrm{~b}=0.0295, \quad \mathrm{c}=-0.0099$

The resulting growth index pattern consistently showed horizontal growth curves at each level prior to the creation of the openings and then a more pronounced growth increase for the border trees after the creation of the openings in 1982. 
Table 2. Radial growth proportions between ground level and DBH (taper) for Border trees and Reference trees, calculated between two 14-year periods before and after the opening. Radial growth at ground level is expected to be larger than at DBH (taper $>100 \%)$. Radial growth at ground level increased only for border trees after opening.

\begin{tabular}{|c|c|c|c|c|c|}
\hline \multirow[b]{2}{*}{ Tree Number } & \multirow[b]{2}{*}{ Number of Trees } & \multicolumn{3}{|c|}{ Radial Growth Proportion Ground Level - DBH (taper) in \% } & \multirow[b]{2}{*}{$\begin{array}{c}\text { Age Difference } \\
\text { Ground Level - } \\
\text { DBH }\end{array}$} \\
\hline & & $\begin{array}{c}\text { After Opening, } \\
\text { Years } \\
\text { 1983-1996 }\end{array}$ & $\begin{array}{c}\text { Before Opening, } \\
\text { Years } \\
1968-1981\end{array}$ & $\begin{array}{l}\text { Proportion of Taper } \\
\text { Between } 2 \text { Periods } \\
\text { After/Before Opening }\end{array}$ & \\
\hline \multicolumn{6}{|c|}{ Border Trees } \\
\hline 061 & & $142.1 \%$ & $120.8 \%$ & $117.6 \%$ & 9 \\
\hline 063 & & $286.6 \%$ & $119.2 \%$ & $240.5 \%$ & 18 \\
\hline 131 & & $133.7 \%$ & $115.0 \%$ & $116.2 \%$ & 3 \\
\hline 167 & & $173.6 \%$ & $129.5 \%$ & $134.1 \%$ & 7 \\
\hline 426 & & $133.7 \%$ & $118.1 \%$ & $113.2 \%$ & 7 \\
\hline 434 & & $114.9 \%$ & $123.3 \%$ & $93.2 \%$ & 18 \\
\hline Mean & 6 & $164.1 \%$ & $121.0 \%$ & $135.8 \%$ & 11.0 \\
\hline Standard Error & & $28.2 \%$ & $2.2 \%$ & $23.7 \%$ & 2.4 \\
\hline \multicolumn{6}{|c|}{ Reference } \\
\hline 109 & & $108.4 \%$ & $101.0 \%$ & $107.4 \%$ & 3 \\
\hline 110 & & $165.3 \%$ & $204.0 \%$ & $81.0 \%$ & 5 \\
\hline 112 & & $99.8 \%$ & $91.4 \%$ & $109.2 \%$ & 14 \\
\hline 114 & & $89.9 \%$ & $115.4 \%$ & $78.0 \%$ & 9 \\
\hline 117 & & $168.7 \%$ & $142.2 \%$ & $118.6 \%$ & 11 \\
\hline 121 & & $120.7 \%$ & $117.9 \%$ & $102.4 \%$ & 23 \\
\hline 456 & & $86.2 \%$ & $125.7 \%$ & $68.6 \%$ & 3 \\
\hline 458 & & $87.6 \%$ & $104.7 \%$ & $83.6 \%$ & 18 \\
\hline 467 & & $79.9 \%$ & $77.6 \%$ & $103.0 \%$ & 13 \\
\hline Mean & 9 & $111.8 \%$ & $120.0 \%$ & $94.6 \%$ & $10-3$ \\
\hline Standard Error & & $11.9 \%$ & $13.0 \%$ & $6.1 \%$ & 2.8 \\
\hline \multicolumn{6}{|c|}{ All trees: Relation Border Trees (mean of 6 ) - Reference Trees (mean of 9) } \\
\hline Mean & & $146.7 \%$ & $100.8 \%$ & $143.5 \%$ & 10.7 \\
\hline Standard Error & & & & & 1.7 \\
\hline
\end{tabular}

Although results using indices were clearer than those using the raw ring-width patterns, the interpretation with both methods is the same. Basal area increment (BAI) would be a more suitable parameter for studying responses of canopy (crown shape and proportion, Table 1), social status and yield in relation to gap management (Dobbertin 1996). Additional information on stand development and stand treatment would be a prerequisite for this approach.

In all the raw-data subsets an above average radial growth was observed between 1920 and 1950: this was partly caused by aging and partly related to temperature effects. A climate model with monthly response functions (Fritts 1976) reveals the following results for the reference trees at DBH:
- Higher temperatures in October of the prior year (i.e. resource storage for early wood) and in May and July of the growing season (Splechtna et al. 2000) have a significant positive effect on growth.

- Growth is positively correlated with precipitation in August and September of the prior year and March of the current year (i.e. predisposing to bud break and start of cambial activity).

- The multiple regression model exhibits a significant first-order autocorrelation and explains $74 \%$ of the growth variation.

At the sub-alpine level, growth of Norway spruce benefits from a small annual temperature increase and the resulting prolonged growing season in spring (Makinen et al. 2002; Dobbertin 1996; Schweingruber 1996). 


\section{CONCLUSIONS}

One hundred-year old sub-alpine Norway spruce trees, usually considered slow growing on a north aspect, are still capable of reaction to sudden increase in resource availability such as light changes. This information is important to foresters managing sub-alpine stands, and encourages them to practice selective management in dense Norway spruce forests established during the second half of the 19th Century.

\section{ACKNOWLEDGMENTS}

We are grateful to Peter Brang, Reinhard Lässig and Andreas Zingg for their valuable counsel and to David Frank and Christian Matter for the English translation. Reviewer's comments have also improved the text. Parts of the results were published as poster abstract 223 in: Conference "Tree Rings and People", September 22-26, 2001, Davos, Switzerland.

\section{REFERENCES CITED}

Becker, M., G. D. Bert, J. Bouchon, J. L. Doupouey, J. F. Picard, and E. Ulrich

1995 Long-term changes in forest productivity in northeastern France: the dendroecological approach. In: Forest Decline and Atmospheric Deposition Effects in the French Mountains, edited by G. Landmann and M. Bonneau, Springer Verlag, Berlin; pp. 143156.

Becker, M., O. U. Bräker, G. Kenk, O. Schneider, and F. H. Schweingruber

1990 Aspect des houppiers et croissance des arbres au cours des dernières décennies dans les régions frontalières d'Allemagne, de France et de Suisse. Rev. For. Fr. XLII-3-1990:284-300.

Bosch, O., L. Gine, E. D. Ramadori, A. Bernat, and E. Gutierrez

1992 Disturbance, age and size structure in stands of Pinus uncinata Ram. Pirineos 140:5-14.

Bräker, Otto U.

1981 Der Alterstrend bei Jahrringdichten und Jahrringbreiten von Nadelhölzern und sein Ausgleich. Mitteilungen der Forstlichen Bundesversuchsanstalt Wien, 142. Heft, 1981, S. 75-102.

Cherubini, P., P. Piussi, and F. H. Schweingruber

1996 Spatiotemporal growth dynamics and disturbances in a subalpine spruce forest in the Alps: a dendroecological reconstruction. Canadian Journal of Forest Research 26(6):991-1001.
Dobbertin, M.

1996 Relationship between basal area increment, tree crown defoliation, and tree and site variables. In: Proceedings, IUFRO Conference on Effects of Environmental Factors on Tree and Stand Growth, Berggiesschübel near Dresden, September 23-27, 1996. Technische Universität, Dresden, Germany: $33-44$.

Esper, J., E. R. Cook, P. J. Krusic, K. Peters, and F. H. Schweingruber

2003 Tests of the RCS method for preserving low-frequency variability in long tree-ring chronologies. Tree-Ring Research 59(2):81-98.

Fritts, H.C.

1976 Tree Rings and Climate. Academic Press, New York; $567 \mathrm{pp}$.

Makinen, H., P. Nojd, H. P. Kahle, U. Neumann, B. Tveite, K. Mielikainen, H. Rohle, and H. Spiecker

2002 Radial growth variation of Norway spruce (Picea abies (L.) Karst.) across latitudinal and altitudinal gradients in central and northern Europe. Forest Ecology and Management 171(3):243-259.

Mayer, H., and E. Ott

1991 Gebirgswaldbau-Schutzwaldpflege. Fischer, Stuttgart, New York; 587 pp.

Mitchell, V. L.

1967 An Investigation of Certain Aspects of Tree Growth Rates in Relation to Climate in the Central Canadian Boreal Forest. Technical Report No. 33, University of Wisconsin, Department of Meteorology, Wisconsin.

Pollanschütz, J.

1966 Verfahren zur objektiven "Abschätzung" (Messung) verminderter Zuwachsleistung von Einzelbäumen und Beständen. Mitteilungen der Forstlichen Bundesversuchsanstalt Mariabrunn, Bd. 73, S. 129-163.

Röhrig, E.

1982 Waldbau auf Ökologischer Grundlage. Paul Parey, Hamburg, Berlin, Bd. 2; 279 pp.

Schütz J. Ph.; Brang P.,

1995 L'horizontoscope: Un Étonnant Outil Pratique de Sylviculture, Notamment en Haute Montagne. ONF Bull. Tech. no. 28-pp. 1-9.

Schweingruber, F. H

1996 Tree Rings and Environment Dendroecology. Swiss Federal Institute for Forest, Snow and Landscape Research, Paul Haupt, Birmensdorf and Berne; 609 pp.

Splechtna, B.E., J. Dobry, and K. Klinka

2000 Tree-ring characteristics of subalpine fir (Abies lasiocarpa (Hook.) Nutt.) in relation to elevation and climatic fluctuations. Annals of Forest Science 57(2): 89-100.

Urban, S. T.

1993 Wood Strength and Annual Ring Width Characteristics of Various Root and Trunk Components of White Spruce Following Partial Canopy Removal. M.S. thesis, University of Alberta, Edmonton; 101 pp.

Received 24 March 2004; accepted 4 June 2006 